\title{
Pascal Chevalier
}

\section{Guillaume Lacquement}

\section{Francuska przestrzeń wiejska. Kategorie i wyobrażenia heterogenicznej wiejskości*}

Streszczenie: Niniejszy artykuł ma na celu przeanalizowanie, jak różne ścieżki rozwojowe wsi francuskich wpłynęły na wyobrażenia wiejskości i kategoryzacje wiejskiej przestrzeni heterogenicznej. Dzięki podejściu historycznemu zobaczymy, w jaki sposób różnorodność umiejscowienia, ścieżek rozwoju społeczno-gospodarczego i wyobrażeń podaje w wątpliwość zasadność stosowania terminu „wiejski” i różne definicje francuskiej wiejskości.

Słowa kluczowe: przestrzeń wiejska, wyobrażenia społeczne, kategorie przestrzenne, Francja.

\section{Wprowadzenie}

Rozważania nad teraźniejszością i przeszłością przestrzeni wiejskiej we Francji zawsze stawiają obserwatora wobec zasadniczej dwoistości dyskursu. Pierwsza jego odmiana, ukształtowana przez ponad stulecie wędrówki ze wsi do miast, odsyła ku analizie upadku świata wiejskiego, który nie mógł bądź nie potrafił się rozwijać. Odmiana druga, bardziej optymistyczna, stara się natomiast pokazać charakter dynamiki wsi, zwłaszcza przez analizę procesów rekompozycji i społeczno-ekonomicznej dywersyfikacji. Historyczne dziedzictwo przestrzeni wiejskiej, ekonomiczne, polityczne i społeczne, częściowo wyjaśnia ową dwoistość dyskursu. Umiejscowienie francuskiej przestrzeni wiejskiej - niekiedy oddalonej od stref wymiany handlowej, a niekiedy zintegrowanej z gospodarką krajową i światową - w procesach wymiany krajowej i międzynarodowej bywa przecież bardzo zróżnicowane. Wobec wielości

Prof. Pascal Chevalier, Université Paul Valéry, UMR CNRS 5281 ART-Dev, Acteurs, Ressources, Territoires dans le Développement, Montpellier, Francja, pascal.chevalier@univ-montp3.fr; prof. Guillaume Lacquement, Université de Perpignan Via Domitia, UMR CNRS 5281 ART-Dev, Acteurs, Ressources, Territoires dans le Développement, Perpignan, Francja, lacqueme@univ-perp.fr.

* Tytuł oryg.: L'espace rural français: catégories et représentations d'une ruralité composite. 
zależnych od poszczególnych obszarów sposobów postępowania trudno zatem narzucić francuskiej wsi jednolity sposób lektury. Czy bowiem można jeszcze mówić o jednej francuskiej wiejskości w odniesieniu do obszarów tak niekiedy odmiennych i tak bardzo rozbieżnych ścieżek rozwojowych?

W niniejszym artykule postanowiliśmy przeanalizować sposób, w jaki różne ścieżki rozwojowe wsi francuskich wpłynęły na wyobrażenia wiejskości oraz definicje statystyczne przestrzeni wiejskiej. W pierwszej części (1) cofniemy się do początków XIX-wiecznej „agrarnej” koncepcji wsi. Zobaczymy wieś jako świat, który nie mógł czy nie umiał osiągnąć stanu nowoczesności uosabianego przez „wielkomiejskość”. Następnie (2) zanalizujemy początki przemian wyobrażeń wiejskości w latach 60 . To wtedy właśnie przekształcenia socjoekonomiczne wsi i towarzyszące im społeczne osłabienie głęboko modernizującego się rolnictwa zachęcały do ponownego przemyślenia świata wiejskiego w kontekście nowych wyobrażeń wiejskości, które przyćmiły jej wizje agrarystyczne i prymitywne. Jednakże pod koniec lat 70. dokonał się wyraźny zwrot w postrzeganiu wiejskości (3). Wieś stała się wtedy nagle przedmiotem dowartościowania w oczach mieszkańców miast, którzy odkrywali w niej świat tradycji i autentyczności. Na zakończenie zobaczymy, jak wraz z nadejściem XXI wieku ekologia oraz, szerzej, społeczna myśl ekologiczna będzie wpływać na kształtowanie się nowej tożsamości francuskiej wsi.

\section{Wiek XIX i agrarystyczna koncepcja wiejskości}

Zdaniem wielu autorów (Bodiguel 1989; Jean, Dionne 2007) „dominujący” dyskurs społeczny dotyczący przestrzeni wiejskich we Francji uległ zasadniczej transformacji wraz z przejściem nowoczesności (zapoczątkowanej XIX-wieczną rewolucją przemysłową) w nowoczesność zaawansowaną (charakteryzującą się tercjaryzacją gospodarki i urbanizacją społeczeństw). W wieku XIX, zasadniczo wraz z rewolucją przemysłową, która dogłębnie zmieniła francuskie systemy produkcji i spowodowała skupienie jednostek produkcyjnych w miastach, to właśnie te ostatnie stały się ucieleśnieniem nowoczesności. Fordyzm i tayloryzm, nowy przestrzenny i społeczny podział pracy marginalizowały stopniowo francuskie wsie, a para pojęciowa miejski/wiejski, pojmowana już wtedy jako dychotomia nowoczesny/tradycyjny, znalazła odzwierciedlenie w idei nieuchronnego zaniku społeczeństwa wiejskiego jako niezdolnego do modernizowania się i transformacji (Béteille 1994).

Odtąd aż do połowy lat 50. XX w. wieś przedstawiała się jako świat, który nie mógł lub nie potrafił osiągnąć stadium nowoczesności charakteryzowanej przez „wielkomiejską" racjonalność. Wiejskość, dewaluowana przez bardzo gwałtownie urbanizujące się społeczeństwo, nadwartościowujące zarazem nową tożsamość 
„miejsko-przemysłowo-usługową, jawiła się zatem jako anachronizm, który musi dostosować się do wymagań czasu przez konieczną urbanizację wsi. Wieś powinna zatem zniknąć - bądź wskutek wchłonięcia przez miasta, bądź w konsekwencji wyludnienia. Jednakże owej „tradycyjnej wsi”, pozostającej na uboczu procesów nowoczesnej industrializacji i zdominowanej przez sektor produkcji rolnej, który w XX w. doświadczyć miał skoku technologicznego i podążać ku modelowi opartemu na wydajności, nieśpieszno było znikać.

Klasyczna koncepcja relacji miasto-wieś, zakładająca sprzeczność i konflikt dwóch odmiennych pod każdym względem typów przestrzeni, przeważa u większości badaczy z dziedziny nauk społecznych. Wieś jest w niej definiowana jako środowisko przyrodnicze, charakteryzujące się przede wszystkim obecnością przestrzeni domowej i rolniczej. Miasto, przeciwnie, to środowisko sztucznie wytworzone, owoc techniki, gdzie przyroda jest niemal nieobecna. Punktem wyjścia do podejmowania zagadnień socjoekonomicznych są zatem strukturalne cechy właściwe perspektywie ludzkiej, związane ze strukturą społeczeństwa i produkcji. Przestrzeń wiejska jest wciąż bardzo często rozpatrywana w terminach przestrzeni rolniczej, na poziomie zarówno diagnozy, jak i perspektyw rozwojowych (Diry 1999; Bonnamour 1997). Tak ujmowana dynamika rolnictwa pozostaje decydującym czynnikiem wyjaśniającym dynamikę obszarów wiejskich w wymiarach społecznym i gospodarczym, ale też $\mathrm{w}$ dziedzinie zagospodarowania przestrzeni oraz wykorzystywania ziemi.

Wędrówka ze wsi do miast, połączona z porzucaniem działalności rolniczej, wzmacniała wspomniany jednofunkcyjny charakter wsi. Ta krytyczna sytuacja skutkowała niewątpliwie stałym osłabianiem istniejącego uprzednio zróżnicowania społeczno-ekonomicznego wsi. Pierre Goubert (1982) mówi w odniesieniu do tego okresu o procesie agrykolizacji środowiska wiejskiego. W klasycznej koncepcji wsi rozróżnianie przestrzeni wiejskich opiera się w istocie na typach działalności rolniczej (monokulturze, polikulturze, systemie intensywnym lub ekstensywnym itd.), jej przemianach (rozpatrywanych często według typologii obszarów wiejskich, do których odwołuje się analiza różnych scenariuszy rozwojowych wsi), typach krajobrazu (pola otwarte i zamknięte) i poziomie rozdrobnienia (małe gospodarstwa i wielkie posiadłości). W omawianej koncepcji główną funkcją wsi jest zaopatrywanie miast w produkty rolne, inną zaś dostarczanie - niezbędnej dla rozwoju przemysłu i usług świata miejskiego - siły roboczej, której coraz większą część uwalnia od pracy na roli postęp technologiczny.

Paradoksalnie jednak pierwsza kategoria statystyczna zastosowana do wsi nie odnosi się do rolniczego charakteru miejscowości. Rozróżnienie gmin wiejskich i miejskich, które w 1864 r. wprowadziło do powszechnych spisów pięcioletnich Biuro Statystyki Generalnej Francji (Bureau de la statistique générale de France), wyznacza pozornie proste kryterium: co najmniej 2000 mieszkańców skupionych 
wokół centrum administracyjnego, czyli merostwa. Próg ten zostanie a posteriori usankcjonowana przez INSEE (L'Institut national de la statistique et des études économiques; Instytut Statystyki i Studiów Ekonomicznych) jako średni próg ujemnej migracji netto w okresie wyludniania się wsi. Można go jednak znaleźć także w państwowych przepisach administracyjnych u schyłku ancien régime’u, w których służył do wzmocnienia kompetencji sędziów pokoju (1790) lub ustanawiania przepisów podatkowych (1816). Wyznaczony na poziomie dość niskim w porównaniu $\mathrm{z}$ innymi krajami, zrywał $\mathrm{z}$ dawną terminologią, która utożsamiała wieś ze zbiorem wiosek, miasteczek i osiedli zdominowanych przez rodziny rolnicze, a jako wyznacznik tradycyjnej definicji miał przetrwać do naszych czasów (Bontron 2015).

\section{Wiejskość między „tradycją" a „nowoczesnością": początki nowych wyobrażeń świata wiejskiego}

W latach 60. powszechne przyspieszenie urbanizacji społeczeństwa i wynikający z szybkiego wzrostu gospodarczego przyrost zatrudnienia zatarły opozycję wiejskości i miejskości (Savy, Veltz 1993; Pierrer-Cornet 2004). Tak oto wkraczamy w fazę wszechmiejskości (phase du tout urbain) (Vanier 2015). Padają zatem pytania, czy w imię metropolizacji i globalizacji długa historia relacji między wsią i miastem ma zakończyć się zniknięciem tej pierwszej i jej ostatecznym wchłonięciem (Benoît, Benoît, Pucci 2002), a zasadność odwiecznej pary „miasto-wieś” (Roncayolo 2001) zaczyna być silnie kwestionowana.

Narastanie migracji ze wsi do miast oraz przyrost udziału ludności nierolniczej są bezsprzeczne. Cechy nowoczesności to rozrastanie się miast i upowszechnianie się miejskiego stylu życia (z samochodem, telewizją itd.). To za jego sprawą urbanizacja przestaje być jedynie konkretnym zjawiskiem przestrzennym, a niektórzy badacze mówią wręcz o urbanizowaniu się wsi (Vanier 2015).

Jeśli jednak „urbanizacja” społeczeństw wiejskich, ich praktyk i zachowań miała zastąpić „tradycyjną i staroświecką” wiejskość, to ta ostatnia przetrwała tu i ówdzie w społeczeństwach, które stały się nowoczesne i miejskie. Według jednych autorów (Diry 1999; Bonnamour 1997) doszło do wzmocnienia oporu ze strony tożsamości wiejskiej, według innych - do stworzenia nowej tożsamości, zbudowanej na odmienności od świata miejskiego i w opozycji do niego. Dlatego prace poświęcone średnim miastom francuskim (Benoît, Benoît, Pucci 2002) dobrze opisują budowanie owej wiejskości „zmityzowanej”, powstałej nie w relacji do specyfiki i dziedzictwa społecznego właściwych wsiom, ale na podstawie rzeczywistych opozycji do wartości wyznawanych przez społeczeństwo miejskie (globalizacja/ lokalizm, indywidualizm/wspólnotowość, nieorganiczny/roślinny). Dobrą ilustracją 
tej tezy jest ruch hippisowski lat 60., który głosił zerwanie z zasadami społeczeństwa konsumpcyjnego, powrót do natury i potępienie indywidualizmu. W ruchu tym, jakkolwiek miał on we Francji charakter bardzo sytuacyjny, niektórzy autorzy (Kayser i in. 1994) upatrują prekursora powszechnego procesu rewaloryzacji nowej tożsamości wiejskiej.

Pomimo dużego znaczenia procesów urbanizacji społeczeństwa wśród naukowych wyobrażeń wiejskości nie natrafia się na takie, w których byłaby ona synonimem społeczeństwa tradycyjnego lub zgoła prymitywnego, skazanego na zniknięcie. Cechy takie bywają oczywiście regularnie przywoływane w dyskursie naukowym. Tym jednak, co zdaje się wciąż przeważać w ówczesnych badaniach, jest uporczywe podkreślanie „odwiecznych” związków wiejskości z chłopstwem, połączone $\mathrm{z}$ trwaniem $\mathrm{w}$ dyskursie wyobrażeń chłopskich społeczności i społeczeństw. Zdaniem badaczy, społeczeństwo chłopskie, jakkolwiek liczebnie mniejsze, pozostaje wciąż społeczeństwem złożonym i zorganizowanym, ale regulowanym przez zasady osłabiane przez nowoczesność i mające tendencję do zanikania. Takie stanowiska naukowe nadal wyraźnie ukierunkowują badania na konkretną grupę społeczną, czyli chłopów, wciąż faktycznie przeważających w społecznościach wiejskich.

W tym okresie polityczne wyobrażenie wiejskości pozostawało, co do ogólnej zasady, dość bliskie wyobrażeniom społecznym i naukowym, a często bywa zgoła ich prostym przekładem. Wtedy również, często w formie zredukowanej i tendencyjnej, odwołującej się do „agrarystycznego" obrazu przestrzeni wiejskiej, umożliwiało ono uruchamianie polityk dowartościowania i modernizacji działalności rolniczej w organizacji wiejskich systemów produkcyjnych. Można w tym miejscu wskazać wiele polityk zwanych „wiejskimi”, które w istocie stanowiły raczej działania wspomagające rolnictwo niż rzeczywiste polityki rozwoju i planowania przestrzennego.

Zróżnicowanie współczesnego rozwoju miast skłoniło INSEE do zmodyfikowania zakresu kategorii statystycznej ustanowionej w połowie XIX w. Krajowy przyrost demograficzny koncentruje się w miastach, co odzwierciedla się we rozroście obszaru zabudowanego i dróg na peryferiach, który często przekracza granice administracyjne. W 1954 r. INSEE wprowadził zatem nową kategorię, mającą uwzględniać likwidację nieciągłości obszaru zabudowanego na obrzeżach największych miast (Marconis 1996). Jednostki miejskie (les unités urbaines) oznaczają, po pierwsze, miasta wyodrębnione (villes isolées), których cała ludność zamieszkuje w granicach administracyjnych gminy; po drugie, wyróżnia się aglomeracje złożone z wielu gmin (agglomérations multicommunales), których granice są wyznaczane podczas każdego spisu na podstawie ciągłości terenu zabudowanego. Wprawdzie podejście statystyczne obiektywnie odzwierciedla morfologiczną definicję miasta, ale ma skłonność do redukowania przyrostu miast jedynie do przyłączania gmin wiejskich ogarniętych przez poszerzające się granice miast. 
Rozproszona urbanizacja i nieciągłości przestrzeni miejskiej wchodzącej w skład aglomeracji spowodowały następnie utworzenie przez INSEE nowej kategorii, przemysłowych i miejskich stref zamieszkania (Zones de Peuplement Industriel et Urbain - ZPIU), zdefiniowanej w 1964 r. na podstawie trzech głównych kryteriów: poziomu codziennych migracji między miejscem zamieszkania i miejscem pracy, wielkości populacji nierolniczej oraz liczby i wielkości istniejących w tych miejscowościach zakładów przemysłowych, placówek handlowych oraz urzędów (Bontron 2015). Zaletą statystycznego podziału na strefy było połączenie tradycyjnych kryteriów morfologicznych z kryteriami funkcjonalnymi, obiektywnie rejestrującymi przemiany społeczno-ekonomiczne współczesnej wiejskości. Zarazem jednak trwale określił on wyobrażenia społeczeństwa dotyczące świata wiejskiego i otworzył drogę dla analiz często sprzecznych w ich diagnozach zagospodarowania i planowania przestrzeni (Marconis 1996).

Gminy wiejskie niebędące ZPIU zostały napiętnowane jako gminy „głęboko wiejskie”, dotknięte przez „pustynnienie”, wyludnienie i porzucanie tradycyjnych form działalności w rolnictwie, rzemiośle i handlu, podczas gdy gminy wiejskie zaklasyfikowane jako ZPIU przeżyły „odrodzenie” napędzane wzrostem populacji i dywersyfikacją społeczno-ekonomiczną.

Obszerna definicja ZPIU do minimum okroiła obszary wiejskie. Według spisu powszechnego z 1990 r. zamieszkiwało je 3,6\% ludności metropolitalnej Francji, a objęły mniej niż jedną czwartą terytorium kraju. Gminy wiejskie charakteryzowały się przy tym bardzo niejednorodną dynamiką demograficzną i społeczno-gospodarczą, głęboko różnicowaną przez bliskość miast i ich wpływ.

W latach 70. obserwowano na wsi rozwój jej wielofunkcyjności oraz działalności pozarolniczej. Obszary wiejskie, gdzie najczęściej dominowało rolnictwo, były zastępowane stopniowo najpierw przez obszary łączące działalność rolniczą i funkcję mieszkaniową, a następnie przez obszary charakteryzujące się rozmaitymi kombinacjami różnych typów funkcji i typów działalności. Ideologia zrodzona w następstwie wydarzeń 1968 r. wzywała wieś do zajęcia nowego, raczej wyidealizowanego niż realnego, miejsca, gdzie staje się ona wsią wynalezioną na nowo (Marié, Viard 1977; Hervieu 1993), nową naturą i przestrzenią wolności dla mieszkańców miast. W gruncie rzeczy jednak mamy tu do czynienia z przedłużeniem zjawisk dekady poprzedniej, charakteryzujących się dalszym odpływem ludności ze wsi do miasta i porzucaniem pracy na roli, i to pomimo kryzysu zatrudnienia, który zmniejszył atrakcyjność miast. Relacje między miastem i wsią zaczynały się zmieniać wraz z tym, jak - wobec kryzysu sztucznego świata miejskiego - nasilało się postrzeganie wsi jako naturalnej i prawdziwej, co wzmacniało jej znaczenie jako środowiska życia (Perrier-Cornet 2002). Wtedy też w dziedzinie badań naukowych pojawił się spór między zwolennikami continuum, gradualnego podziału przestrzeni 
według stopnia upowszechnienia się miejskiej nowoczesności, a wyznawcami koncepcji swoistości świata wiejskiego (uwzględniającej wszelkie rozróżnienia typów obszarów wiejskich).

\section{Wiejskość coraz bardziej doceniana}

Dość wyraźna zmiana postrzegania wsi dokonuje się we Francji pod koniec lat 70., a zwłaszcza w latach 80. (Giddens 1987). Wieś, wciąż jeszcze opisywana jako tradycyjna i zatopiona $\mathrm{w}$ przeszłości, staje się przedmiotem nadwartościowania w oczach mieszkańców miast, którzy odkrywają w niej świat „autentyczności”. Świat wiejski staje się światem lokalnym, światem początków, ku któremu powinny zwrócić się miejskie społeczeństwa zachodnie, zdezorientowane nagłym, zapoczątkowanym w latach 80., przyspieszeniem globalizacji. Uświadomienie sobie trwałości kryzysu, zwłaszcza w wymiarach społecznym i ekonomicznym, w których niepowstrzymanie narastają bezrobocie, ubóstwo i niepewność jutra, sprzyja zatem pojawieniu się ideologii lokalizmu. Wobec dokonujących się na poziomie międzynarodowym przemian ekonomicznych, na które lokalni aktorzy zdają się nie mieć wpływu, zalecana w dziedzinie przedsiębiorczości zasada small is beautiful („,małe jest piękne") wydaje się pewnym rozwiązaniem. Znajduje ona swój przestrzenny równoważnik w ponownym odkryciu rozwoju lokalnego, wspieranego wdrażaniem polityk decentralizacji lub regionalizacji.

W tym samym czasie, zwłaszcza pod koniec lat 80. - za sprawą problemu wielkich podmiejskich osiedli (banlieus), uświadomienia sobie skutków zanieczyszczenia, anonimowości i ogólnej dolegliwości życia w mieście - obraz otoczenia miejskiego staje się negatywny. Otoczenie wiejskie zaś nie bywa już utożsamiane po prostu z przeszłością i społeczeństwem tradycyjnym, ale z nowym, ożywczym sposobem życia, który pozwala jednostce odkryć na nowo wolność w środowisku cechującym się ludzką skalą. Naturalnie zerwanie $\mathrm{z}$ anonimowością, a przede wszystkim akceptacja przez społeczność wiejską, zdolną zdecydowanie odrzucać pewne inicjatywy, nie są oczywiste, co jednak w niczym nie zmienia pragnień nowych mieszkańców wsi. W zestawieniu z szalejącymi w ośrodkach miejskich zagrożeniami wieś istotnie wydaje się bezpieczna i cicha: mniejsza gęstość zabudowy mieszkaniowej i sąsiedzkie stosunki oferują pewną jakość życia, która decyduje o - nie zawsze uświadamianej - wiejskiej codzienności: „wieś uspokaja, stabilizuje, martwi i niepokoi miasto" (Ferras 1990, s. 20). Podczas gdy miasto, a zwłaszcza megamiasta, wpisują się coraz bardziej w procesy globalizacji, świat wiejski staje się w oczach coraz liczniejszych osób, zwłaszcza mieszkających w miastach, środowiskiem, które procesom tym częściowo się wymyka. To przestrzeń, gdzie inicjatywa jednostek lub gospodarstw domowych wciąż umożliwia 
przezwyciężanie zewnętrznych ograniczeń czy to w dziedzinie mieszkaniowej, czy to na polu aktywności gospodarczej i tworzenia miejsc pracy. Dla osób przedsiębiorczych i poszukujących społecznego uznania wielkość społeczności i przedsiębiorstw wiejskich odgrywają rolę pierwszoplanową, zwłaszcza przez wzgląd na zjawisko anonimowości generowane w miastach (Kayser 1990). Również poszukiwanie korzeni, zarówno rzeczywistych, jak i przybranych, może prowadzić do wyboru miejsca osiedlenia: tożsamość, pamięć i wyobraźnia mogą związać tego lub owego mieszkańca miasta $\mathrm{z}$ tą lub inną wsią.

Pewien skromny udział w ponownym odkrywaniu lokalności miało również samo rolnictwo. Porwane przez wir globalizacji rynków i międzynarodową redystrybucję wielkich ilości produktów podstawowych - zbóż, mięsa, owoców i warzyw, rozwija produkcję lokalnych artykułów rolnych i kwalifikowanych, związanych z konkretnym miejscem (Dedeire 2004). Utwierdzenie się i wzrost popytu na nie, najczęściej wychodzącego z miast, sprzyja tym tendencjom, z których korzystają zwłaszcza tereny wiejskie najmniej przystosowane do przyjęcia wymogów konkurencji międzynarodowej.

Obraz społeczności wiejskiej, naznaczony wagą i swoistością działalności rolniczej (nawet jeśli ta ostatnia, w dużej mierze przekształcona, zachowała się jedynie szczątkowo w gospodarce i strukturze zatrudnienia), nadal pozostaje bardzo żywy w umysłach mieszkańców miast. Wakacyjne pobyty, festiwale żniwne, targi produktów rolnych i inne przejawy inspiracji wiejskich, a także powstawanie wiejskich muzeów podtrzymują wyobrażenie przyjaznego środowiska i dziedzictwa zasługującego na ochronę i dowartościowanie, miejsca, w którym żyje się dobrze. Pomimo dramatycznych wstrząsów, jakich zaznała wiejska przestrzeń - takich jak zanik ludności chłopskiej i przekształcenia rodzajów produkcji rolnej - obraz wiejskości tradycyjnej i zdominowanej przez rolnictwo rodzinne, ów odwieczny ład pól ${ }^{1}$ przetrwa w mitach i w ich inscenizacjach (Lévy 1994).

W rzeczywistości jednak, wskutek złożoności odniesień i narzędzi analizy, koncepcja wiejskości ponownie traci na ostrości. W ścieżkach rozwojowych, którymi do owego czasu podążają obszary wiejskie, wyraźnie zaznaczają się nieciągłości. Spisy powszechne ludności przeprowadzane regularnie we Francji i wsiach eurośródziemnomorskich potwierdzają, że główną rolę w odnawianiu się populacji wiejskich odgrywają zjawiska migracyjne. Odmłodzenie, następujące wskutek przybycia nowych, młodszych grup ludności, oddziałuje na naturalne czynniki demograficzne i stopniowo równoważy poziom przyrostu naturalnego, na który

1 „Odwieczny ład pól” (oryg. „un ordre éternel des champs”) to sformułowanie zapożyczone od Rolanda Maspétiola, zasłużonego badacza wsi francuskiej, autora książki pod tym właśnie tytułem wydanej w 1946 r. [przyp. tłum.]. 
negatywnie wpływał, często stuletni, exodus. Do tego dokładają się inne znaczące procesy powiązane z przemianami społecznymi, czyniąc wszelką uogólnioną interpretację lub analizę jedynie cząstkową. Osłabienie społeczeństwa chłopskiego w sprawowaniu lokalnej władzy, ponowne zaludnienie przez populacje zazwyczaj niejednorodne, narastający dystans między miejscem zamieszkania i miejscem pracy, poprawa w dziedzinie mieszkalnictwa wiejskiego, rozwój nowych form zamieszkania krótkoterminowego, spowodowane zauroczeniem zieloną turystyką, wielokrotny przyrost liczby wyjazdów wypoczynkowych i rekreacyjnych ludności miast poszukujących przestrzeni i kontaktu z przyrodą to również czynniki, które skomplikowały ramy analizy (Hervieu, Viard 2001).

Nowe formy konsumpcji obejmują skrajnie zróżnicowane aspekty i wymiary działalności gospodarczej, spośród których krótkoterminowy najem sezonowy należy do najczęstszych i najbardziej dostrzegalnych (Chevalier 2002). Powiązania między takim najmem a stałym zamieszkiwaniem są liczne i wywołują prawdziwy efekt synergii, sprzyjający ponownemu zaludnianiu się wsi nawet na obszarach odległych od wielkich ośrodków miejskich. Za pośrednictwem generowanej konsumpcji funkcje turystyczne łączą się z funkcjami produkcji rolniczej i nierolniczej obecnymi już w środowisku wiejskim (Chevalier 2002), choćby dzięki wprowadzaniu na rynek produktów lokalnego rolnictwa lub rzemiosła. Można też ponownie mówić o industrializacji wsi i narastającej aktualności kwestii ekologicznych.

Wspomniana złożoność ram analitycznych sprawiła, że zdaniem licznych badaczy nie istnieje już opozycja wiejskości i miejskości, a jedynie zróżnicowania natężenia procesów i cech (demograficznych, ekonomicznych itd.). Przyjąwszy taką optykę, nie dopuszcza się definicji dychotomicznej, gdzie posługiwanie się jednym terminem wyklucza drugi, a wiejskość określa się jedynie przez zaprzeczenie. Jeśli nawet większość słowników poświadcza jeszcze istnienie owej minimalnej definicji pary wiejski/miejski, wszystkie zgadzają się co do tego, że jest ona pod wieloma względami niezadowalająca i wymaga zniuansowania. Zaznaczmy najpierw, że mamy tu do czynienia z pojęciem względnym: bez trudu można wyobrazić sobie, że daną przestrzeń łatwo zaklasyfikować jako wiejską w kraju gęsto zaludnionym z gęstą siecią ośrodków miejskich niż w innym, mniej zaludnionym i słabo zurbanizowanym. Przestrzeń jest zatem mniej lub bardziej wiejska lub przeważnie wiejska, nie zaś wyłącznie wiejska lub miejska. Przede wszystkim jednak jakiekolwiek bezwzględne rozróżnienie staje się trudne: możemy zgodzić się co do tego, że na obszarach wiejskich mieszka mniej ludzi, niewiele jest też aktywności wymagających ich skupienia, takich jak produkcja przemysłowa na wielką skalę, usługi kulturalne i handel dobrami rzadkimi. Niemniej jednak istnieje tam oczywiście sektor przemysłowy, napędzany niekiedy przez prawdziwe okręgi przemysłowe, a także dynamiczne lokalne sektory produkcyjne. Dominuje sektor 
usługowy, czy to związany z administracją, czy to z turystyką lub opieką zdrowotną; stanowi on czasami aktywność napędzającą rozwój wsi (Chevalier 2005a). Choć Bernard Kayser bronił jeszcze istnienia „specyficznych tożsamości i wyobrażeń silnie skojarzonych z kulturą chłopską" (Kayser 1990, s. 455), to jednak ów fundament tożsamości wiejskiej nie wydaje się już wyłącznie związany z daną przestrzenią; miejskość utwierdza się więc nie tylko w nieokreślonej przestrzeni podmiejskiej, ale też w samych wsiach. Czyżby zatem sama wiejskość, paradoksalnie, miała być bardziej obecna w wyidealizowanych i nostalgicznych wyobrażeniach mieszczuchów niż w realnym świecie mieszkańców obszarów wiejskich?

Wiejskość bywa - jeśli nawet jest to teza sama w sobie dyskusyjna - coraz częściej utożsamiana z lokalnością, lokalność zaś odróżniana od miejskości (Lascoumes, Le Galès 2012). Nowe typologie powstają w odniesieniu do obszarów o charakterze niepewnym oraz związków między przestrzenią, środowiskiem i kryteriami społecznymi. Aby odnieść się do tego zagadnienia, przedstawiono wiele koncepcji. Podmiejskie obszary wiejskie, wielorako powiązane z miastem i przejawiające rosnącą dynamikę społeczno-gospodarczą i demograficzną, odróżniały się od obszarów o charakterze głęboko wiejskim. Te ostatnie charakteryzuje się więc poprzez ich marginalne położenie geograficzne, $z$ dala od miast $i$ arterii komunikacyjnych, przez słabą gęstość zaludnienia oraz niewydolność lokalnej tkanki społeczno-gospodarczej. Rzeczywistość wydaje się jednak bardziej złożona. W dużej części swych prac badacze wykazali, że przestrzenie wiejskie, słabo zaludnione i na pierwszy rzut oka klasyfikowane jako zmarginalizowane, mogą pochwalić się dobrą kondycją dzięki procesom restrukturyzacji sektora rolniczego lub dzięki rozwojowi innych sektorów, na przykład turystyki (Bontron 2015). Inne typologie podejmują analizę procesów różnicowania się przestrzeni za pomocą pojęć aneksji, integracji i asocjacji (Terluin 2003) i poprzez próby charakteryzowania każdego z typów logiką jego związków z systemem produkcyjnym szczebla krajowego. Wyróżnia się zatem obszary przedindustrialne, obszary opanowane przez konkurencyjne rolnictwo i obszary skolonizowane przez turystykę masową (Jollivet 2009), jednak taki model wyjaśniający wysuwa na pierwszy plan procesy dominujące, które w ten lub inny sposób podporządkowują sobie obszary wiejskie i narzucają im kierunek rozwoju.

W sprawie statystycznych określeń wsi wiele głosów sprzeciwia się redukowaniu pary miejski/wiejski do sumarycznej dychotomii, popierając ideę continuum, czyli gradualnego przechodzenia jednego typu przestrzeni w inny. Coraz większą nieufność budzą definicje stosujące proste progi skupisk ludności. Jeśli nawet ustanawianie takich progów na użytek analiz jest nadal konieczne, to powinny one być udoskonalane i brać pod uwagę przemiany europejskiej wiejskości. O ile zatem zachowanie podejścia dychotomicznego w niektórych definicjach urzędowych wskazywało na względne opóźnienie namysłu nad obszarami wiejskimi, ich 
funkcjonowaniem i specyfiką socjologiczną, o tyle zarysowało się stopniowe dążenie do uwzględniania niuansów i podejścia opartego na gradualizmie. Aby zatem uniknąć ujmowania świata wiejskiego w sposób zbyt uproszczony, wprowadza się we Francji progi pośrednie, tworząc w ten sposób kategorie takie, jak „półmiejski/półwiejski”, „wiejski zurbanizowany”, „wiejski podmiejski”, a nawet „wiejsko-miejski”, które przybliżają nas do oglądu obszarów wiejskich w perspektywie continuum.

Prowadzone przez DATAR (Délégation interministérielle à l’aménagement du territoire et à l'attractivité régionale; Międzyresortowa Delegatura ds. Planowania Przestrzennego i Atrakcyjności [turystycznej] Regionów) badania prognostyczne, nie lekceważąc konsekwencji wpływu miast, uwzględniają impulsy endogenne i ich wpływ na dynamikę wsi. Zróżnicowanemu odnawianiu się populacji gmin wiejskich towarzyszą oryginalne formy adaptacyjne lokalnej gospodarki (Kayser 1990). INSEE zaproponował następnie w 1997 r. użycie nowych kryteriów statystycznych, które odmienią społeczne postrzegania organizacji przestrzeni (Marconis 1997). Kategorie, które zostaną zastosowane wstecznie do spisu powszechnego z 1990 r., a następnie do spisu z 1999 r., wprowadzają pojęcia przestrzeni z dominantą miejską oraz przestrzeni $\mathrm{z}$ dominantą wiejską. Na pierwsze $\mathrm{z}$ nich składają się obszary miejskie, łączące wielkie centra miejskie $\mathrm{z}$ ich otoczeniem podmiejskim. Definiuje się je na podstawie kryteriów funkcjonalnych (5000 zatrudnionych w głównym ośrodku miejskim i 40\% osób przemieszczających się codziennie do pracy z gmin podmiejskich). Podobne funkcjonalne kryteria stosuje się również do obszarów wiejskich, przy czym część progów obniżono, co pozwoliło wyróżnić ośrodki zatrudnienia na obszarach wiejskich (1500 zatrudnionych), ich otoczenie (40\% aktywnych zawodowo pracujących w ośrodku wiejskim) oraz inne gminy. W wyniku zastosowania takiego podziału strefowego przestrzeń z dominantą wiejską w spisie powszechnym z 2006 r. objęła 18\% ludności kraju i 58\% jego powierzchni. Modyfikuje on przede wszystkim sposób postrzegania polityk zagospodarowania przestrzennego, pozwalając na zmniejszanie nierówności między poszczególnymi obszarami dzięki uwzględnianiu potencjalnych impulsów płynących z małych miast, a także umocowuje przepisy wspierające lokalne inicjatywy, takie jak europejski program LEADER, działające na rzecz rozwoju terytorialnego.

Wszystko to uzasadnia wysoką temperaturę polemik, z którymi spotkało się wprowadzenie w 2010 r. nowego Podziału Stref Obszarów Miejskich (Zonage en Aires Urbaines), który spowodował zniknięcie wsi z ujęć statystycznych. Ustanowił on trójstopniową hierarchię biegunów miejskich (bieguny wielkie, bieguny średnie, bieguny małe), odróżnianych na podstawie liczby zatrudnionych (powyżej 10 000, 5000 do 10 000, 1500 do 5000) i opasanych przez podmiejskie pierścienie, wyróżniane na podstawie liczby podróży wahadłowych, ustanowionej nadal na 
poziomie 40\% osób czynnych zawodowo (Brutel, Lévy 2011). Przestrzeń nieobjęta tymi kategoriami została określona mianem "gmin izolowanych, znajdujących się poza wpływem biegunów miejskich", a obszary $\mathbf{z}$ dominantą wiejską zniknęły. Wprawdzie dla celów zachowania ciągłości statystyki tradycyjna definicja, służąca do wyodrębniania gmin i operująca progiem 2000 mieszkańców, została utrzymana w mocy, jednakże nie pozwala ona scharakteryzować współczesnej wiejskości. Dokonany wybór staje po stronie interpretowania sposobu funkcjonowania przestrzeni na podstawie skutków metropolizacji i mobilności mieszkaniowej, jednak zdaje się mylić urbanizację i rozlewanie się miast ze wzrostem budownictwa i poszerzaniem się obszarów zamieszkania. Co więcej, lekceważy on wpływ miast na migracje zarobkowe osób czynnych zawodowo i znaczenie przejazdów lokalnych (Bontron 2015), a także, skądinąd, stoi w sprzeczności z dynamiką wskazaną przez tych samych statystyków w obrębie zagłębi życiowych (bassins de vie); trzy czwarte tych obszarów zidentyfikowano w 2012 r. jako wiejskie ${ }^{2}$. We wszechmiejskiej wizji statystyków wyrażają się trudności i sprzeczności pojmowania wiejskości współczesnej, i to mimo tego, że badania prognostyczne przysporzyły nam przecież licznych typologii mających na celu odzwierciedlenie zróżnicowania francuskiej przestrzeni wiejskiej w zakresie krajobrazu, struktury ekonomicznej i warunków życia (DATAR 2012).

\section{Coraz większy udział ekologii w postrzeganiu wiejskości}

Przełom w myśleniu naukowym na temat wsi dokonał się w 1990 r. m.in. z powodu ukazania się we Francji książki Bernarda Kaysera Rok 1990 (Kayser 1990). Okres ten wydaje się wprawdzie przedłużeniem tendencji dekady poprzedniej, ale w kontekście całkowicie zmienionym, zarówno w Europie Zachodniej, jak i w Europie Środkowej, mającej za sobą wielki przewrót.

Pogłębienie się we Francji kryzysu zatrudnienia, który rozszerzył się na warstwy społeczne dotąd nim niedotknięte, wpłynęło w głównej mierze na miasta. Problemy wielkich osiedli podmiejskich i kryzys miasta spowodował zerwanie z obrazem nowoczesności, który z biegiem lat ukształtował przestrzeń miejską. Równolegle narastające skutki globalizacji dopominały się o zmianę dominujących wyobrażeń społecznych.

2 Podział strefowy na zagłębia życia został wprowadzony przez INSEE w 2002 r. w celach analizy struktury przestrzeni wiejskiej na podstawie stopnia dostępu mieszkańców do usług pośrednich (Julien, Pougnard 2004). W ramach podziału wyodrębniono 1666 zagłębi, z których - w rozumieniu kryteriów Komisji Europejskiej - 1287 miało charakter wiejski, stanowiąc $78 \%$ powierzchni kraju i 31\% jego ludności (Brutel, Levy 2012). 
Od tego czasu począwszy, dość niespodziewanie, nowa tożsamość wiejska miała się uformować za sprawą ekologii i nowej ekologicznej myśli społecznej. Wieś zyskuje wtedy w obiegowych, dowartościowujących ją wyobrażeniach bardzo wyraziste konotacje, a jej postrzeganie nie jest już związane wyłącznie z działalnością produkcyjną. Nowe kierunki badań pod egidą OCDE (2013) (Organisation de coopération et de développement economiques; Organizacja Współpracy Gospodarczej i Rozwoju; OECD - Organisation for Economic Co-operation and Development) jasno pokazują narastające oddzielanie się rolnictwa i przestrzeni wiejskiej. W oczach społeczeństwa obywatelskiego, zwłaszcza miejskiego, o wiejskości wsi decyduje już nie rolnictwo, ale przyroda. Postawy takie mogą w największym stopniu powodować zmiany percepcji własnego środowiska życia w przypadku mieszkańców przedmieść.

Równolegle ważne miejsce w obecnym postrzeganiu wiejskości zajmuje krajobraz. Jest on postrzegany w kategoriach estetycznych, przy czym nie jest to już wyłącznie krajobraz tworzony przez działalność rolniczą, nawet jeśli jest ona praktykowana. Ale to właśnie rolnictwo, bardziej niż działalność produkcyjna w ścisłym znaczeniu, odpowiadać ma za dobre zarządzanie przyrodą. Krajobraz jest tu polem gry, gdzie natura, ceniony przedmiot troski i ochrony, przeciwstawiona jest działalności rolniczej - przemysłowej i dążącej do wydajności, obarczonej współwiną za degradację środowiska i postrzeganego w coraz mniejszym stopniu jako część środowiska wiejskiego.

Można powiedzieć, że zbiorowa troska o środowisko naturalne wtargnęła do przestrzeni wiejskiej i ukazała ją w nowym świetle. Wraz z rozwojem nowoczesności pojawia się wyobrażenie wsi jako środowiska, w którym krajobrazy są dobrami publicznymi, należącymi do całego społeczeństwa, a nie tylko do samych mieszkańców wsi.

Jednak taka wizja środowiska wiejskiego jest skrajnie redukcjonistyczna, wieś bowiem nie jest bynajmniej tak „naturalna”, jak mogą ją postrzegać mieszkańcy miast. Dominujące wyobrażenie społeczne wsi jak „naturalnej” może prowadzić do pewnych napięć między ludnością miejską, która często oczekuje, że mieszkańcy wsi będą zarządzać przestrzenią w sposób zgodny z ich oczekiwaniami co do krajobrazu, kultury czy żywności, nie zaś kierując się własną wolą. I rzeczywiście, wskutek - niekiedy bardzo rozbieżnych wyobrażeń - nowa wiejskość staje się często przyczyną nieporozumień i konfliktów między poszczególnymi grupami ludności. W efekcie mieszkańcy wsi bardzo często czują się pozbawieni własnej ziemi i prawa do rządzenia się na niej.

W dyskursie politycznym, wciąż zgodnym z wyobrażeniem wiejskości coraz bardziej otwartej na kwestie środowiska, wyraża się zamiar opracowania nowych recept mających zapewnić „zrównoważony rozwój” wsi. Idea modernizacji obszarów 
wiejskich i rolnictwa, celująca w zwiększenie ich produktywności, ustępuje zatem miejsca idei ochrony społeczności i terenów, postrzeganych nieomal jako obszar klęski ekologicznej, gdzie zapewnienie przetrwania zagrożonych gatunków wymaga troski władz publicznych. Dlatego właśnie ich „interwencjonizm” będzie w coraz większej mierze zastępował „wspieranie”, czego dowodzą liczne europejskie polityki wiejskie (takie jak programy LEADER). Dyskurs „budowniczych Europy” i podejmowane w zgodzie z nim działania czynią zatem ze wsi sprawę całego świata (przestrzeń wiejska jest tu dobrem wspólnym, które należy chronić lub wykorzystywać rozsądnie). Dzieje się tak ku wielkiemu utrapieniu zaniepokojonych mieszkańców wsi, zdaniem których - nawet jeśli zgadzają się z najnowszą wersją filozofii zrównoważonego rozwoju - wsi potrzeba prawdziwych polityk rozwoju lokalnego.

Poza ramy wyznaczone przez efektywność rolnictwa wykracza obecnie nawet jego polityczne postrzeganie, niegdyś silnie wiążące świat wiejski z rolnictwem. Tam, gdzie z powodu niekorzystnych lokalnych ograniczeń i w obliczu krajowych i międzynarodowych imperatywów gospodarczych perspektywy produkcji rzeczywiście wydają się niezbyt zachęcające, rolnictwu powierza się zadania ochrony krajobrazu i opieki nad przyrodą. Wywołuje to debatę nad rolą rolnika jako ogrodnika natury, która to rola znajduje potwierdzenie w krajowych i europejskich politykach ochrony środowiska. Wprowadzenie komponentu środowiskowego Wspólnej Polityki Rolnej w połowie lat 90. poświadcza centralną pozycję ochrony środowiska w praktykach rolniczych, obok dążenia do rentowności lub produktywności, czemu towarzyszą koncepcje zrównoważonego rozwoju oraz wzmacniania się tendencji do - choćby częściowego - kwestionowania znaczenia efektywności w rolnictwie. Tak oto uprawomocnienie działalności rolnictwa polega już nie tylko na jego funkcji dostarczania żywności, ale także na zdolności do zarządzania krajobrazem, środowiskiem przyrodniczym, terytorium, czyli wsią lub obszarami wiejskimi.

Opowiadanie się za potrzebą rozwoju lokalnego i dążenie do niego, jako odpowiedź na procesy globalizacji lub ich uzupełnienie, podsyca spory wokół pojmowania lokalnych ojczyzn oraz sposobu ich identyfikowania, narzuca też gminom i ich społecznościom konieczność współpracy. Wieś, jako pojęcie tracące część swojego przestarzałego charakteru, staje się - wbrew oczekiwaniom - pewnym projektem. Kryzys fordyzmu i ideologii liberalnej, powodujących pogoń za produktywnością, przyczynił się do wzmocnienia koncepcji obszaru wiejskiego jako przestrzeni mało spolaryzowanej i w małym stopniu poddanej konkurencji rynkowej.

Choć na polu badań naukowych zwolennicy idei słabnięcia odrębności terenów wiejskich zyskują rozgłos i są wciąż dość liczni (Perrier-Cornet 2002; Depraz 2005), to jednak inni badacze dążą do ukazania narastającej homogenizacji przestrzeni i społeczeństw oraz do ponownego wprowadzenia do debaty zagadnień przyrodniczych i środowiskowych. Naukowy dyskurs na temat europejskiej wiejskości 
stopniowo przesuwa się ku postrzeganiu świata wiejskiego jako pewnego środowiska. Ten nowy obszar studiów, dotąd umiarkowanie rozpoznany przez badaczy wsi, staje się kierunkiem badań o rosnącym znaczeniu. W nauce europejskiej po długotrwałym zainteresowaniu urbanizacją wsi (ten ważny temat, skądinąd, miał doprowadzić do kryzysu w łonie samych studiów nad wsią) przypomniano sobie dziś o wielkim znaczeniu kwestii ekologicznych, a środowisko życia stało się decydującą, różnicującą zmienną (Chevalier 2005b).

Tym, co dziś, po wkroczeniu naszych społeczeństw w nowoczesność, wydaje się częścią wspólną ewolucji naukowych wyobrażeń wiejskości jest, przypuszczalnie, powszechna zgoda co do zniknięcia społeczeństw wiejskich bądź chłopskich jako społeczeństw globalnych. Wiejskość trwa, ale wahamy się jak, lub brakuje nam pojęć, by ją scharakteryzować. Zwróciliśmy się ku kwestiom przestrzennym i środowiskowym. Wielu uczonych specjalizujących się w tematyce wiejskiej upatruje w nich nowej szansy dla wsi, dziś bowiem, gdy mamy wątpliwości co do istnienia pewnych wyrazistych cech socjoekonomicznych wsi, jej definiowanie jako środowiska stanowi nową obietnicę troski ze strony władz publicznych.

\section{Zakończenie}

Mając na uwadze niejednoznaczny charakter dynamiki przestrzeni wiejskiej we Francji w okresie od XIX w., różnorodność sytuacji, ścieżek rozwojowych i wyobrażeń, stawialiśmy sobie w niniejszym artykule pytanie o to, czy mówienie o wiejskości stanowi najlepszy sposób ujmowania tak wielkiej różnorodności. W istocie koncepcja wiejskości z konieczności ewoluowała wraz ze zmianami na wsi, które wpływały również na przestrzeń wiejską. Zmiany, które zaszły w ciągu ostatniego stulecia, prowadzące od wiejskości rolniczej do opartej na usługach i turystyce, są ogromne. Przemiana zamkniętego świata w zurbanizowany świat wiejski, przemiana wsi zatopionej w przeszłości i sfunkcjonalizowanej w wieś coraz bardziej cenioną, ponowne odkrycie przez osamotnionych mieszkańców miast wartości wspólnoty lokalnej w środowisku wiejskim - oto głębokie zmiany, które domagają się stałego kwestionowania różnych definicji świata francuskiej wsi.

tłum. Michał Wójtowski

\section{Bibliografia}

Benoît J.-M., Benoît P., Pucci D. (2002). La France à 20 minutes. La révolution de la proximité. Paris: Editions Belin.

Béteille R. (1994). La crise rurale. Seria: Que Sais-je? Paris: PUF. 
Bodiguel M. (1989). La campagne, quelle campagne? W: M. Bodiguel, P. Lowe. Campagne française, campagne britannique (s. 13-28). Paris: L'Harmattan.

Bonnamour J. (1997). La géographie rurale pendant le dernier quart de siècle. Ruralia 1. http://journals.openedition.org/ruralia/5 [dostęp: 01.01.2003].

Bontron J.-C. (2015). La dimension statistique de la ruralité - Une manière de lire les représentations et les évolutions du rural. Pour, 228, GREP, 57-67.

Brutel C., Lévy D. (2011). Le nouveaux zonage en aires urbaines, 95\% de la population vit sous l'influence des villes. Seria: INSEE Première, nr 1374.

Brutel C., Lévy D. (2012). Le nouveau zonage en bassins de vie de 2012, trois quarts des bassins de vie sont ruraux. Seria: INSEE Première, nr 1425.

Chevalier P. (2002). Dynamiques tertiaires de l'espace rural. Montpellier: Presses Universitaires de la Méditerranée.

Chevalier P. (2005a). Activités tertiaires et dynamiques rurales. Revue des Annales de Géographie, 641, 27-48.

Chevalier P. (2005b). Les nouvelles relations ménages/entreprises et les liens urbain/rural. W: S. Arlaud, Y. Jean, D. Royoux (red.). Urbain-Rural: Nouveaux liens, nouvelles frontières (s. 175-189). Rennes: Presses Universitaires de Rennes.

DATAR (2012). Typologie des campagnes françaises et des espaces à enjeux spécifiques. Rapport de Synthèse rédigée par M. Hilal, A. Barczak, F.-P. Tourneux, Y. Schaeffer, M. Houdart, D. Cremer-Schulte. Paris: DATAR (wersja online: http://www.observatoire-des-territoires.gouv.fr/observatoire-des-territoires/fr/typologie-des-campagnes-fran-aises-et-des-espaces-enjeux-sp-cifiques-littoral-et-montagne [dostęp: 9.02.2018]).

Dedeire M. (2004). Dynamiques économiques des paysages à travers les biens tangibles reconnus: l'exemple des produits d'origine géographique. W: Lévaluation du paysage: une utopie nécessaire (s. 107-122). Montpellier: édition Presse de l’Université Montpellier III.

Depraz S. (2005). Vers une définition internationale du rural en Europe. W: A. Berger, P. Chevalier, G. Cortes, M. Dedeire. Héritages et trajectoires rurale en Europe (s. 85-108). Paris: L'Harmattan.

Diry J.-P. (1999). Les espaces ruraux. Seria: Campus. Paris: SEDES.

Ferras R. (1990). Ville paraître, être à part. Montpellier: GIP Reclus.

Giddens A. (1987). La constitution de la société. Seria: Sociologies. Paris: PUF.

Goubert P. (1982). La vie quotidienne des paysans français au XVII siècle. Paris: Hachette.

Hamman P. (red.) (2017). Ruralité, nature et environnement, entre savoirs et imaginaires. Toulouse: Erès.

Hervieu B. (1993). Les champs du futur. Julliard: éditions François Bourin.

Hervieu B., Viard J. (2001). L’Archipel paysan. La Tour d'Aigues: L’Aube.

Hilal M., Barczak A., Tourneux F.-P., Schaeffer Y., Houdart M., Cremer-Schulte D. (2012). Typologie des campagnes françaises et des espaces à enjeux spécifiques. Territoires en mouvement, 7.

Jean B., Dionne S. (2007). La ruralité entre les appréciations statistiques et les représentations sociales: comprendre la reconfiguration socio-spatiale des territoires ruraux Québécois. Norois, 202, 9-19. 
Jolivet M. (1974). Les collectivités rurales françaises. T. 2: Sociétés paysannes ou lutte de classes au village. Paris: Armand Colin.

Jollivet M. (2009). Un temps fort de la sociologie rurale française. Études rurales, 183, 67-82.

Julien P., Pougnard J. (2004). Les bassins de vie au cœur de la vie des bourgs et des petites villes. INSEE Première, 953.

Kayser B. (1990). La Renaissance rurale, sociologie des campagnes du monde occidental. Paris: A. Colin.

Kayser B., Brun A., Cavailhes S., Lacombe P. (1994). Pour une ruralité choisie. Datar/éditions de l'Aube, coll. „Monde en cours”.

Lascoumes P., Le Galès P. (2012). Sociologie de l'action publique (wyd. 2). Paris: Armand Colin.

Lévy J. (1994). Oser le désert. Sciences Humaines, 4, 6-9.

Marconis R. (1996). Le territoire français, XIXème-XXème siècles. W: Histoire de France. T. 2: Sociétés et cultures (s. 7-50). Presses Universitaires du Mirail.

Marconis R. (1997). Villes et campagnes, l'évolution des zonages statistiques en France. Historiens et Géographes, 356, 181-189.

Marié M., J. Viard (1977). La campagne inventée. Le Paradou: Actes Sud.

Mathieu N. (1982). Questions sur les types d'espaces ruraux en France. L'Espace Géographique, 247 (2), 95-110.

Mathieu N. (1990). La notion du rural et les rapports ville-campagne en France: des années cinquante aux années quatre-vingts. Economie rurale, 197, 35-41.

Mathieu N. (1998). La notion du rural et les rapports ville-campagne en France: les années 90. Economie rurale, 247, 11-19.

Mathieu N., Férault C. (2012). Les nouveaux rapports à la nature dans les campagnes. Paris: Ed. Quae.

OCDE (2013). Partenariats rural-urbain: une approche intégrée de développement économique. Bruxelles: Editions de l'OCDE.

Perrier-Cornet P. (2002). Repenser les campagnes. Paris: éditions de l'Aube.

Perrier-Cornet P. (2004). Lavenir des espaces ruraux. Futuribles, 299, 77-95.

Roncayolo M. (2001). Histoire de la France urbaine: La ville aujourd'hui - Mutations urbaines, décentralisation et crise du citadin. Poche.

Savy M., Veltz P. (red.) (1993). Les Nouveaux Espaces des entreprises. DATAR/éditions de l'Aube.

Terluin I.J. (2003). Differences in economic development in rural regions of advanced countries: An overview and critical analysis of theories. Journal of rural studies, 19 (3), $327-344$.

Vanier M. (2015). Réforme territoriale et espace rural. Pour, 272, GREP, 147-153. 


\title{
French Rural Space: Categories and Representations of a Composite Rurality
}

\begin{abstract}
The aim of this article is to analyse how the different evolutionary trajectories of the French countryside have influenced the representations of rurality and the categorizations of a composite rural space. Through a historical approach, we will see how the heterogeneity of situations, the trajectories of socio-economic evolution and the representations question the relevance of the term "rural" and systematically put into question the different definitions of rural France.
\end{abstract}

Keywords: rural space, representations, spatial category, France. 